\title{
ERRATUM
}

\section{Evidence for Nipah virus recrudescence and serological patterns of captive Pteropus vampyrus - ERRATUM}

\author{
A. R. SOHAYATI, L. HASSAN, S. H. SHARIFAH, K. LAZARUS, C. M. ZAINI, \\ J. H. EPSTEIN, N. SHAMSYUL NAIM, H. E. FIELD, S. S. ARSHAD, \\ J. ABDUL AZIZ, P. DASZAK and EcoHealth Alliance
}

doi: 10.1017/S0950268811000550, Published by Cambridge University Press, 28 April 2011.

In the article by A. R. Sohayati, L. Hassan, S. H. Sharifah, K. Lazarus, C. M. Zaini, J. H. Epstein, N. Shamsyul Naim, H. E. Field, S. S. Arshad, J. Abdul Aziz, P. Daszak and EcoHealth Alliance presented in Epidemiology and Infection, there was an error in the name of the final author [1]. The correct authorship is:

A. R. Sohayati, L. Hassan, S. H. Sharifah, K. Lazarus, C. M. Zaini, J. H. Epstein, N. Shamsyul Naim, H. E. Field, S. S. Arshad, J. Abdul Aziz, P. Daszak and HERG.

We apologise to HERG and the readers for this omission.

The affiliation of HERG (Henipavirus Ecology Research Group) is EcoHealth Alliance, New York, USA.

\section{REFERENCE}

1. A. R. Sohayati, L. Hassan, S. H. Sharifah, K. Lazarus, C. M. Zaini, J.H. Epstein, N. Shamsyul Naim, H. E. Field, S. S. Arshad, J. Abdul Aziz, P. Daszak and EcoHealth Alliance Evidence for Nipah virus recrudescence and serological patterns of captive Pteropus vampyrus. Epidemiology and Infection, Available on CJO 2011 doi: 10.1017/S0950268811000550. 